\begin{tabular}{|c|c|c|c|c|c|c|}
\hline \multirow{4}{*}{ Impact Factor: } & ISRA (India) & $=3.117$ & SIS (USA) & $=0.912$ & ICV (Poland) & $=6.630$ \\
\hline & ISI (Dubai, UAE & $=0.829$ & РИНЦ (Russia) & $=0.156$ & PIF (India) & $=1.940$ \\
\hline & GIF (Australia) & $=0.564$ & ESJI (KZ) & $=8.716$ & IBI (India) & $=4.260$ \\
\hline & JIF & $=1.500$ & SJIF (Morocco) & $=5.667$ & OAJI (USA) & $=0.350$ \\
\hline
\end{tabular}

\section{SOI: $1.1 /$ TAS $\quad$ DOI: $10.15863 /$ TAS \\ International Scientific Journal Theoretical \& Applied Science}

p-ISSN: 2308-4944 (print) e-ISSN: 2409-0085 (online)

Year: $2019 \quad$ Issue: $07 \quad$ Volume: 75

Published: $24.07 .2019 \quad$ http://T-Science.org
QR - Issue

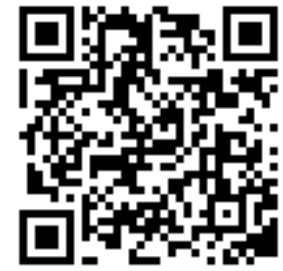

QR - Article

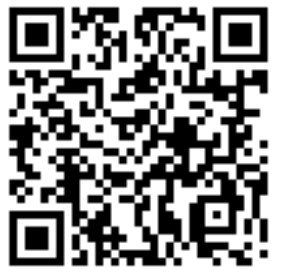

Rahimjon Boltaboyevich Kodirov Andizhan State University

Candidate of Geographical Sciences, Assistant Professor, Head of the chair of "Geography", Republic of Uzbekistan

\title{
THE DYNAMICS OF POPULATION AND DEMOGRAPHIC PRESSURE (on the material of Fergana region)
}

\footnotetext{
Abstract: This article analyzes the relationship between demographic pressure and population growth, demographic territory, and the region, population, GDP, and per capita indicators.

Key words: population dynamics, demographic pressure, demographic pressure coefficient, regions, per capita GDP and its size.

Language: English

Citation: Kodirov, R. B. (2019). The dynamics of population and demographic pressure (on the material of Fergana region). ISJ Theoretical \& Applied Science, 07 (75), 260-264.

Soi: http://s-o-i.org/1.1/TAS-07-75-41 Doi: croskef https://dx.doi.org/10.15863/TAS.2019.07.75.41

Classifiers: Geography. History. Oceanology. Meteorology.
}

\section{Introduction.}

As the evolutionary progression of the population is consistent with the laws of economic and social life, certain changes are taking place in demographic processes. Consequently, historical, economic and social development, and political processes play an important role in the demographic situation [2, p.127].

Population growth is one of the characteristics of Uzbekistan. For example, in 1991 the population of the republic was 20607,7 thousand people, in 2018 it was more than 32656,7 thousand people [7, p.18] In the short period of time, the population of the country increased to 12049,0 thousand or $158,5 \%$.

Indeed, one of its main features is the high rates of birth and natural growth rates in the republic. The increase in the number of indigenous people in recent years and the acceleration of urbanization have also had an impact on demographic processes. At the same time, the mentality typical to the Oriental people, the demographic outlook and changes in the population, and the negative migration balance of the population remain in effect $[3$, p.5].

\section{Research methods.}

Fergana valley is one of the regions with unique demographics and socio-economic development. The area is 18,5 thousand sq.km. and makes up only $4,2 \%$ of the country's total territory. In 2018, 28,6 per cent of the country's population is in the region, 16,5 per cent of GDP, 18.5 per cent of industrial production, 26,4 per cent of agricultural output [9, p.11-12] .

Data analysis shows that in the Fergana region, the population is higher than the area, the gross domestic product, and especially the industrial output. Therefore, the growing demographic pressure in the region has attracted many researchers. Before we can talk about demographic pressure, let's just say some about the pressure.

According to the laws of physics, "pressure is the force that is affecting the surface of the body and normally directed to the surface" [5, p.346]. Pressure simply can be described as: "The force acting on the surface is called pressure." It is represented by the following formula:

$$
\boldsymbol{P}=\frac{\boldsymbol{F}}{\mathbf{S}}
$$

Here: $\mathbf{F}$ - force, $\mathbf{S}$ - surface.

Economic geography and demography can be introduced as follows: the unity surface - the region, the power of influence - the growing population in the period.

In the National Encyclopedia of Uzbekistan, the pressure is described as "pressure is a physical quantity representing the intensities of a body that moves upwardly on the surface of another body" [8, p.160]. 


\begin{tabular}{|c|c|c|c|c|c|c|}
\hline \multirow{4}{*}{ Impact Factor: } & ISRA (India) & $=3.117$ & SIS (USA) & $=0.912$ & ICV (Poland) & $=6.630$ \\
\hline & ISI (Dubai, UAE & $=0.829$ & РИНЦ (Russia & $=0.156$ & PIF (India) & $=1.940$ \\
\hline & GIF (Australia) & $=0.564$ & ESJI (KZ) & $=8.716$ & IBI (India) & $=4.260$ \\
\hline & JIF & $=1.500$ & SJIF (Morocce & $=5.667$ & OAJI (USA) & $=0.350$ \\
\hline
\end{tabular}

If we consider the surface area as a region, and the power of influnce as the number of population from this physical concept, we will have the following simple definition of the demographic pressure:

Demographic pressure is the intensified influence of population on the region over a given period of time. As demographic pressure, 1 sq. km. economic and social complexes consisting of population, intensive agricultural lands, water and recreational resources, food, industrial development, housing and communal services, and transport. It is represented by the following formula:

$$
P=\frac{N}{S}
$$

Here: $\boldsymbol{P}$-demographic presure, $\boldsymbol{N}-$ number of population and natural resources, $S-$ square $[5, \mathrm{p}$ 346].

Demographic pressure at the beginning of the period is the same as that of the region. However, the population growth will result in increased demographic pressure and population density. It can be seen that the population density depends on the demographic pressure given to the area. Thus, if the region, population and socioeconomic indicators are known, demographic pressure can be easily identified.

Demographic pressure is the ratio between the population and the level of natural resource availability of the region. An increase in the population will lead to increased demographic pressure. This will result in a decline in the natural resource supply coefficient. This will give greater emphasis to socio-economic issues and will allow rationalization of production capacities, especially industrial sectors, in the regions.

Prof. Y.I.Ahmadaliyev points out the following opinions about agro-demographic pressure, considering that the population's economic activities are closely related to agricultural lands: "The first block will explore the agro-demographic type of agricultural anthropogenic pressure. Indicators for this type of agricultural anthropogenic pressure are estimated as the number of rural population (in person) per 1 sq. Km and per capita (hundredth) irrigated cropland "[1, p.78-79].

Prof. A.S.Soliev described the demographic pressure in the Ferghana region as follows: "The Fergana Valley ... has a big demographic burden, with an average household size. The combined effects of population and the economy are characterized by specific stress, strong antropogenic pressure. Therefore, the main socio-geographical problem of the region should be to simplify this pressure and create appropriate conditions for the life and activity of the population. Indeed, high demographic pressure, low water and shortage of land and water resources require the development of new, modern industrialinnovative development strategies and trends in the socio-economic development of the region "[4, p.243].

Summarizing the above mentioned data, the demographic pressure factor can be used as follows: Here:- coefficient of demographic pressure;

- the number of the population of the region explored, the complex of natural resources and socioeconomic indicators;

- the population of the country, the complex of natural resources and socio-economic indicators.

Based on this coefficient, a comparative analysis of the demographic and regional economic and social issues of the regions is being carried out.

In calculating demographic pressure, the population of the republic performs its duty as denominator. Demographic pressure of the population is equal to 0,20 in the Zarafshan region, the southern region is 0,17 , the Lower Amu-Darya region is 0,11 , the Mirzachul region is 0,06 , and the Fergana region equals to the coefficient of 0.28 . The demographic pressure factor across the country is extremely high in the Ferghana region due to the population density. The demographic pressure coefficient is also high in the Zarafshan region, with moderate rates in the southern region and low indicators in the Lower Amudarya and Mirzachul regions (Table 1).

Table 1. Some comparative indicators of the regions of the republic (01.01.2018)

\begin{tabular}{|l|l|l|l|l|l|l|}
\hline № & Regions & $\begin{array}{l}\text { Area, } \\
\text { thousand } \\
\text { sq.km }\end{array}$ & $\begin{array}{l}\text { Share as to } \\
\text { area, } \\
\text { percentage }\end{array}$ & $\begin{array}{l}\text { Number of } \\
\text { population, } \\
\text { thousand } \\
\text { people }\end{array}$ & $\begin{array}{l}\text { Share as to } \\
\text { number } \\
\text { population, } \\
\text { percentage }\end{array}$ & $\begin{array}{l}\text { Coefficient } \\
\text { depographic pressure of } \\
\text { regions }\end{array}$ \\
\hline 1 & Tashkent & 15,59 & 3,5 & 5326,1 & 16,3 & 0,16 \\
\hline 2 & Mirzachul & 25,49 & 5,7 & 2140,9 & 6,6 & 0,06 \\
\hline 3 & Ferghana & 18,50 & 4,1 & 9331,5 & 28,6 & 0,28 \\
\hline 4 & Zarafshan & 168,08 & 37,4 & 6548,3 & 20,0 & 0,20 \\
\hline 5 & Southern & 48,67 & 10,8 & 5662,6 & 17,3 & 0,17 \\
\hline 6 & $\begin{array}{l}\text { Lower } \\
\text { Amudarya }\end{array}$ & 172,64 & 38,5 & 3647,3 & 11,2 & 0,11 \\
\hline
\end{tabular}

The table is made by the author based on data of the state statistics committee of the republic 


\begin{tabular}{|c|c|c|c|c|c|c|}
\hline \multirow{4}{*}{ Impact Factor: } & ISRA (India) & $=3.117$ & SIS (USA) & $=0.912$ & ICV (Poland) & $=6.630$ \\
\hline & ISI (Dubai, UAE & $=0.829$ & РИНЦ (Russia & $=0.156$ & PIF (India) & $=1.940$ \\
\hline & GIF (Australia) & $=0.564$ & ESJI (KZ) & $=8.716$ & IBI (India) & $=4.260$ \\
\hline & JIF & $=1.500$ & SJIF (Morocce & $=5.667$ & OAJI (USA) & $=0.350$ \\
\hline
\end{tabular}

During the exploration period from 1991 to 2018 , the population of the republic grew by $158,5 \%$. The highest population growth rates were observed in the southern region $(187,1 \%)$. Lower Amu-Darya $(156,1 \%)$ and Zarafshan $(160,6 \%)$ regions has medium rate. The lowest indicator was recorded (125,0 percent) in the Tashkent region. Population growth rates, in turn, have increased the share of some regions (South and Ferghana), but contributed to a decrease in the share of the Lower Amu-Darya and Tashkent regions in the national population. Thus, in 1991 , the Southern region covered $14,7 \%$ of the total population of the republic, and its share in 2018 has increased significantly and increased by $17,3 \%$. This process will continue in the future, and by 2050 its share will reach $20,1 \%$.

The share of Ferghana region increased from $26,9 \%$ (1991) to $28,6 \%$ (2018). The contribution of this region is expected to grow in the future and will rise by $31 \%$ in 2050. The share of the Lower AmuDarya region decreased by $0,1 \%$ in 2018 compared to 1991. In 2050, 10,9\% of the population in the republic is predicted to correspond to this region. While the share of the Tashkent region is 20,7 percent at the beginning of the period, it dropped to 16,3 percent in 2018. According to estimates, the share of the region in the country will continue to decline in the future, and by 2050 it will be $13,7 \%$ [6, p.127-130] and will decrease by 7,0\% compared to 1991 (picture 1).

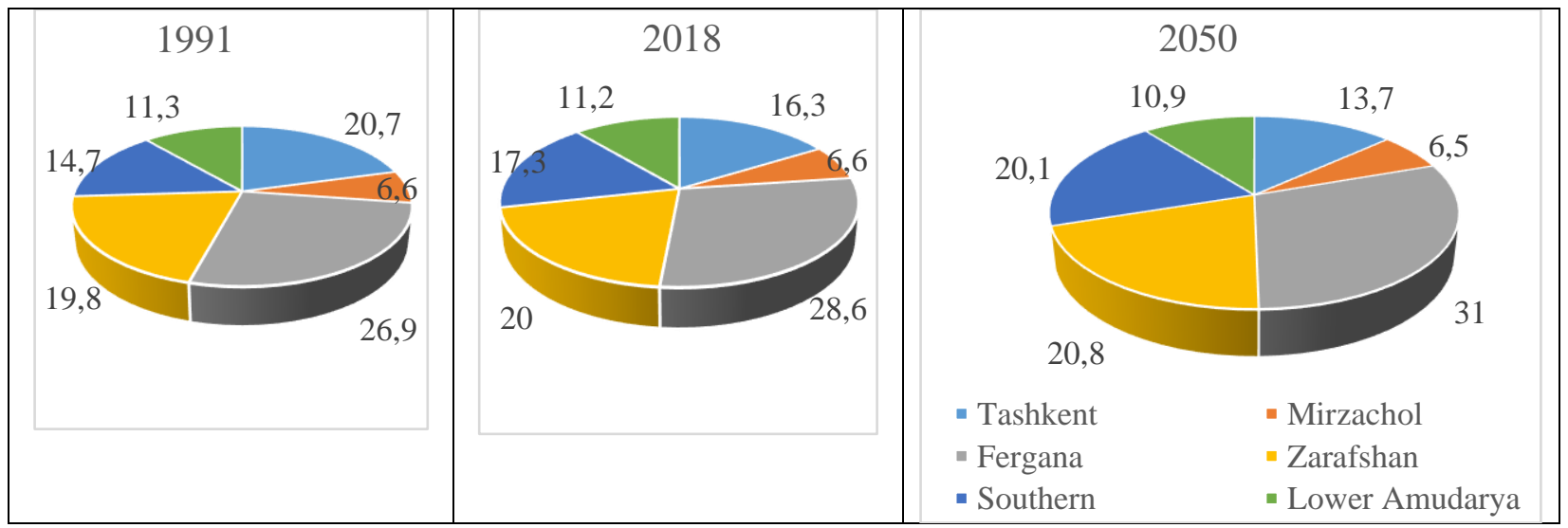

Picture 1. Change in the share of regions according to the number population

As you know, the data on the volume of GDP and their per capita distribution are one of the main socio-economic indicators of the regions and on the basis of which certain conclusions are reached on the social status of the population.
GDP in the republic in 2018 will reach 407514,5 billion soums and increased by $5,1 \%$ compared with 2017 [10].

Table 2. Gross Domestic Product of the Republic of Uzbekistan and per capita distribution (2018)

\begin{tabular}{|l|l|l|l|}
\hline & GDP in billion soums & $\begin{array}{l}\text { Per capita GDP in } \\
\text { thousand soums }\end{array}$ & $\begin{array}{l}\text { Share of regions in GDP, } \\
\text { percentage }\end{array}$ \\
\hline Republic of Uzbekistan & $\mathbf{4 0 7 5 1 4 , 5}$ & $\mathbf{1 2 3 6 5 , 6}$ & $\mathbf{1 0 0 , 0}$ \\
\hline $\begin{array}{l}\text { Republic } \\
\text { Karakalpakstan }\end{array}$ & $\mathbf{7 4 1 8 5 , 2}$ & 7642,9 & 3,5 \\
\hline Andijan & 27121,6 & 8923,9 & 6,7 \\
\hline Bukhara & 21151,9 & 8830,3 & 5,2 \\
\hline Jizzakh & 11820,2 & 8830,3 & 2,9 \\
\hline Kashkadarya & 28412,2 & 8932,1 & 7,0 \\
\hline Navoiy & 21729,0 & 22489,1 & 5,3 \\
\hline Namangan & 18141,4 & 6654,7 & 4,5 \\
\hline Samarkand & 31187,4 & 8295,8 & 7,7 \\
\hline Surkhandarya & 17061,9 & 6712,5 & 4,2 \\
\hline Syrdarya & 8200,5 & 9966,6 & 2,0 \\
\hline Tashkent & 38398,7 & 13333,4 & 9,4 \\
\hline Fergana & 25181,2 & 6895,7 & 6,2 \\
\hline Khorezm & 15154,2 & 8325,6 & 3,7 \\
\hline Tashkent city & 53287,1 & 21419,4 & 13,1 \\
\hline
\end{tabular}




\begin{tabular}{|c|c|c|c|c|c|c|}
\hline \multirow{4}{*}{ Impact Factor: } & ISRA (India) & $=3.117$ & SIS (USA) & $=0.912$ & ICV (Poland) & $=6.630$ \\
\hline & ISI (Dubai, UAE & $=0.829$ & РИНЦ (Russia & $=0.156$ & PIF (India) & $=1.940$ \\
\hline & GIF (Australia) & $=0.564$ & ESJI (KZ) & $=8.716$ & IBI (India) & $=4.260$ \\
\hline & JIF & $=1.500$ & SJIF (Morocce & $=5.667$ & OAJI (USA) & $=0.350$ \\
\hline
\end{tabular}

Tashkent region is dominated by GDP volume. In particular, the largest share of the republic was found in the city of Tashkent (53287, 1 billion soums), while Tashkent region (38398,7 billion soums) occupies the next place. The share of Samarkand region is $(31187,4$ billion soums) more than Zarafshan region and the share of Kashkadarya region is (28412,2 billion soums) more than the Southern region. In Fergana region, while Andijan (27121,6 billion soums) and Fergana (25181,2 billion soums) regions have made more products, they have indicators among the regions. Regions are characterized by the small size and weight of the
Mirzachul region. In particular, in Syrdarya region 8200,5 billion soums were created, which made up 11820,2 billion soums in Jizzakh region (Table 2).

In the Republic in 2018 the average per capita income was 12365,6 thousand soums, in Navoi region it was equal to 22489,1 thousand soums and it was the highest among the regions of the republic. The gross domestic product made up 21419,4 thousand soums in Tashkent and took the second place. Also, GRP per capita in Tashkent region exceeded the national average. It should be noted that the GDP per capita is lower than the national average.

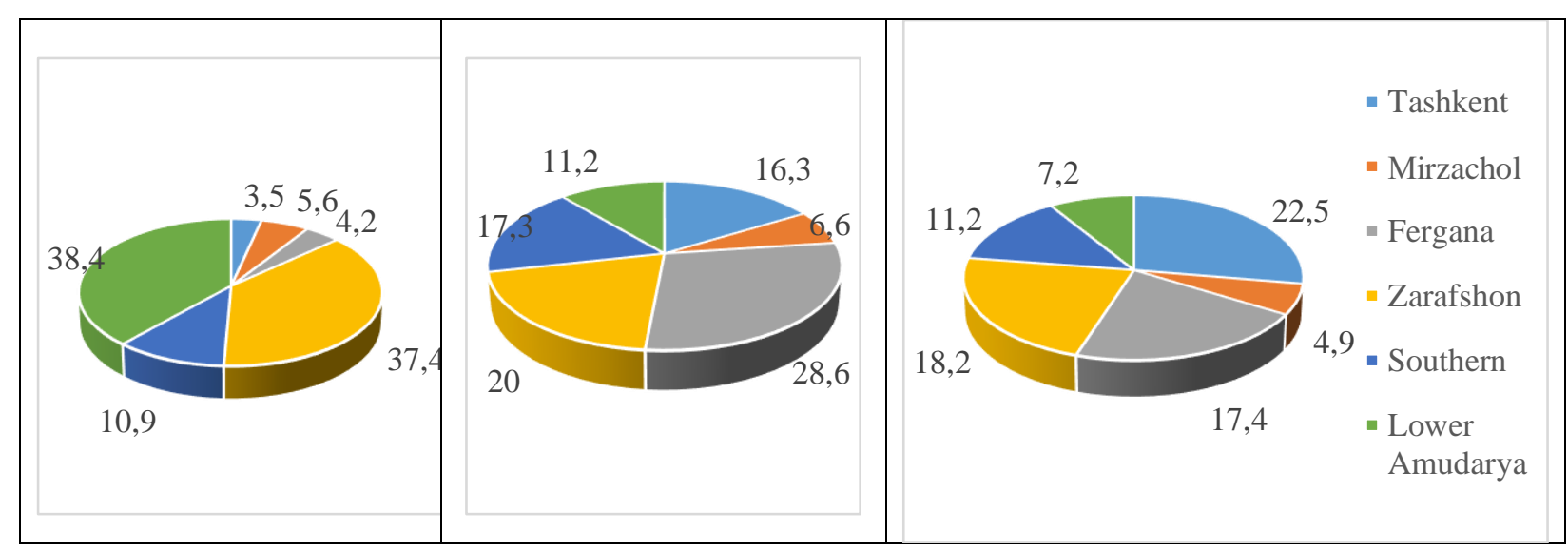

Picture 2. Regions, population and GDP share, percentages

According to the analysis, the Tashkent region is one of the highest in terms of urban and socioeconomic development, especially in terms of gross domestic product and industrial output. As the size of the Lower Amu-Darya region is the biggest, it prevails over all regions, occupying the lowest population and GDP in the republic. However, the Fergana region, which is the largest in terms of size and size of population, occupies the second place in the country after Tashkent and Zarafshan regions. In this region, per capita GDP is below the national average. In the region where the demographic pressure is high, the decline in basic human and economic indicators, correspondingly, requires rapid development of the industrial sector (Picture 2).

\section{Conclusion.}

Demographic pressure is rising in all regions of the country. Taking into account that this process will continue in the future, to mitigate and promote the population migration in regions with relatively less populated and natural resources to reduce demographic pressure, including money rewards, establishment of housing and tax rates at zero redundancy, improving labor resources use, the creation and support of innovative projects, including migration businesses in foreign countries [2, p.127] and labor migration, creating conditions for private entrepreneurship and business in the key industries agricultural, industrial and social infrastructures are the main tasks.

\section{References:}

1. Ahmadaliev, Y. I. (2014). Geoecology of Land Resources Use. (pp.78-79). Tashkent: Science and technology.

2. Kayumov, A. A., Yakubov, O. S., \& Abdullaev, A. G. (2011). Principles of population geography and demography. Tashkent: Science and Technology.

3. Qodirov, R. B. (2016). Population and labor resources in the Ferghana region. (p.168). Tashkent: Navruz. 


\begin{tabular}{|c|c|c|c|c|c|c|}
\hline \multirow{4}{*}{ Impact Factor: } & ISRA (India) & $=3.117$ & SIS (USA) & $=0.912$ & ICV (Poland) & $=6.630$ \\
\hline & ISI (Dubai, UAE & $=0.829$ & РИНЦ (Russia & $=0.156$ & PIF (India) & $=1.940$ \\
\hline & GIF (Australia) & $=0.564$ & ESJI (KZ) & $=8.716$ & IBI (India) & $=4.260$ \\
\hline & JIF & $=1.500$ & SJIF (Morocce & $=5.667$ & OAJI (USA) & $=0.350$ \\
\hline
\end{tabular}

4. Soliev, A., et al. (2010). Socio-economic development of regions of Uzbekistan. (p.243). Tashkent: Mumtoz soz.

5. Strelkov, S. P. (1977). Mechanics. (p.346). Tashkent: Ukituvchi.

6. Temirov, Z. (2018). Forecasting population size in Fergana region. Information, Tashkent, Volume 53, pp.127-130.
7. (2018). Demographic Yearbook of Uzbekistan. (p.18). Tashkent.

8. (2001). National Encyclopedia of Uzbekistan. Tashkent: National Encyclopedia of Uzbekistan, Volume 2, p.160.

9. (2018). Annual statistical collection of regions of Uzbekistan. (p.11,16). Tashkent.

10. (n.d.). website information. Retrieved 2019, from www.Stat.uz 